\title{
REPORT OF THE EXTENSION COMMITTEE OF THE FARM ECONOMIC ASSOCIATION.
}

The committee decided to make an analysis of the farm management extension activities for the past year. Such a report seemed to follow logically the questionnaire sent to agricultural extension leaders by the Extension Committee of last year asking the ways in which effective farm management extension work could be accomplished.

This analysis is based upon the monthly and annual reports of the farm management demonstrators and other extension workers. The main activities are listed as follows.

I. Fight hundred and ninety county agents report the distribution of farm acount books in their counties. The reports from the farm management demonstrators in the northern and western states show the distribution of over 225,000 farm account books for use during 1920. Also, a number of southern states distributed a large number of account books. Other agencies such as banks and coöperative farmers' organizations have been instrumental in distributing the account books prepared by the state agricultural colleges. These facts are significant only in so far as they show that wide distribution of simple and practical farm account books has been secured throughout practically all states of the Union. This wide dissemination of farm account books in many states has practically eliminated the distribution of other types of farm account books. A great impetus has been given farm accounting by income tax legislation, which has resulted in a demand for farm account record books and for information in farm accounting.

2. No adequate report is available showing the extent to which farm records are kept and summarized as many books are kept without assistance. However, 45 county agents report assisting farmers to summarize 13,872 accounts. In addition the farm management extension workers have assisted is summarizing many records. Five hundred and eleven county agents report 30,255 farm records summarized to their knowledge. It is known that many county agents assisted with this work but made no mention of it in their annual reports. The plan of work in many states includes summarizing and analyzing at least a few records in a county as a means of helping county agents to recognize the most important economic questions 
relating to agriculture and to provide local demonstration material. The number of records reported summarized were from the account books distributed for the year I9I9.

3. A number of states have held schools of instruction in farm accounting, cost acounting and other agricultural economic questions for county agents and other leaders in sectional or state meetings of county agents. Reports of such schools indicate that they have proved a potent means of giving the county agents a clear understanding of the aims of farm management. This type of work is especially desirable in many states due to the continually changing personnel of the county agent forces.

4. Fifteen states report holding approximately 500 farm management schools of instruction for groups of farmers. By "schools" is meant the assembling of groups of farmers to work out problems pertaining to their own farm operations. The school method of instruction has been adapted especially to teaching the keeping of farm accounts. Most of these schools consisted in part of having a group of farmers go through the process of entering a typical farm record in a blank record book as a means of teaching them to keep, summarize and analyze the record of their own farm business. Such a record offers a good basis for discussing factors having to do with the success of farming. The "school method of instruction" has proved popular because it affords an opportunity of extending the work to a large number of farmers; it is an effective method of teaching the farmers to keep their own records; and it is a type of work which county agents, agricultural high school teachers and other can duplicate. With the tremendous growth of farm bureau work and interest in agricultural economics it is important that the farm management extension work be developed in a way that will enable the county agents and other leaders to conduct much of the work without the immediate assistance of the farm management extension specialist. In connection with the instruction in record keeping there is an increasing tendency to follow up definitely records started with farmers as a means of securing local demonstration material to be used as a means of demonstrating the best farm organization and management under given conditions. Several states are drawing up definite projects with county farm bureau associations arranging for the completion of definite farm management demonstration work in a specific county. This work in the main contemplates the summarizing of general farm accounts or cost accounts for local demonstration use for meetings, publicity, or farm tours. 
5. Reports from a total of 35 states show that approximately i 500 general meetings have been held with groups of farmers for the purpose of teaching farm management principles and to clemonstrate the effect of certain factors on the farm earnings. Among the more important factors emphasized are the choice of farn enterprises, the size of business, the yield and quality of crops, the amount and quality of livestock, economical disposition of feeds, the farm layout, the means of securing efficient use of man and horse labor, and the use and distribution of capital. Also much attention is given to presenting material in a way which enabled county agents and other leaders to use the material throughout the year. In many states this work is handicapped from lack of adequate investigational data.

6. Assistance in enterprise cost accounting work has been given in most of the states conducting farm management extension work. After interest has been aroused in the study of the farm business many men wish to make a more detailed study of the most important enterprises in their farm business. This promises to be one of the best means of helping farmers to analyze their business in a way that will help them determine means of securing more efficient production. Much of the public interest in this phase of work may be due to the agitation resulting from price fixing activities during the war. However, the information secured either from the cost accounting records or from meetings where cost of producing a product is determined. through estimate by a group of farmers is accomplishing much in bringing about a right understanding concerning the relationship of cost of production to price. The greatest value to the farmer resulting from enterprise records is in showing how production may be accomplished more efficiently.

7. A number of states have prepared exhibits which have been put on at both state and county fairs. One of the most successful exhibits has been the model of a farm showing desirable characteristics in the layout and organization of the farm. An exhibit of this type has been used in ten states. The success of this exhibit undoubtedly was due to its realistic appearance resulting from showing the growing crops and the clearness with which it depicted desirable farm lay-out and practices. The model of a farm exhibit has proved an excellent means of securing the coopperation of specialists in the subject matter clepartments in working out a plan of farm organization adapted to a region. Also, where this exhibit has been extended to county fairs it has been a means of getting the county agent to think through the desirable type of farm organization for the region. 
The activities enumerated above indicate the most important activities carried on during the past year. Other activities which have been started in a small way and which give promise of further extension include:

I. Arranging farm management tours as a means of demonstrating good farm practices. The farms visited on such tours are selected to demonstrate definite farm management principles and the records kept on the farms form the basis of the demonstration especially if it pertains to the profitableness of farming.

2. Work on improving tenancy contracts through both meetings and work with individuals. This work has included the preparation of lease forms adapted to a region and demonstration meetings with farmers for the purpose of showing desirable provisions to include in leases, and promoting the spirit of coopperation between landlords and tenants.

3. The formation of farm management clubs with groups of boys of high school age or younger men on the farms for the purpose of keeping, summarizing and analyzing the records on their home farms and studying the means of securing more efficient farm production.

4. Assistance to agricultural high schools in outlining a method of instruction and plan of work where farm management is made the home project of the student.

5. Planning a simple outline for teaching the fundamentals of farm accounting to be used in grade school instruction in rural communities.

Farm management extension work together with the investigational work has been a potent factor in building county and community farm burcau programs of work along sound economic lines.

In conclusion, it should be stated that farm management extension work, including the analysis of individual farm records, the schools for instruction in farm accounting and farm business analysis, the subjects discussed in general meetings, the analysis of enterprise cost records, the preparation of exhibit material, the selection of demonstration field material, the improvement in tenancy conditions and the preparation of subject matter for club and school work all emphasize the need of more and continued investigation and the preparation of investigational material in form suitable for extension teachirig.

Investigational data coming into the hands of extension workers and more especially to county agents is in a fragmentary state. There is a need of assembling the facts as a definite guide for practical farm organization and management. Due to the constantly changing economic conditions, investigational work needs to be continued and 
its interpretation for extension teaching should be kept up to date. This need is the result of the early farm management extension activities which were devoted primarily to work with individual farmers, helping them to analyze and study their business. This type of work helped develop a greater public interest in the economic side of farming and a natural result is the call for more information based on actual investigation.

\section{H. C. M. CASE,}

Chairman.

\section{TENTATIVE PROGRAM, I92I, AMERICAN FARM ECONOMIC ASSOCIATION. TWELFTH ANNUAL MEETING.}

\section{William Pexn Hotel, Pittspurgi, Pa., December 29, $30,31$.}

I. To what extent are the Farmers' Credit Needs being Adequately Met?

Discussion, E. S. Bayard, Editor, National Stockman and Farmer.

2. The Farmer's Share of the Social Dividend and His Prospects for the Future.

Paper, Professor David Friday, Pres. Michigan Agricultural College.

Discussion, L. C. Gray.

3. The Outlook for Coöperative Marketing.

Paper, Prof. E. G. Nourse, Iowa State College.

Discussion, Theodore Macklin, University of Wisconsin, and J. R. Howard, Pres. American Farm Bureau Federation.

4. Short Time Credit Needs in Producing and Marketing Farm Products.

Paper, Dr. Ivan Wright, University of Illinois.

Discussion, Representative of Iowa Credit Association.

5. President's Address :

Research in Agricultural Economics and Farm Management, W.

F. Handschin, University of Illinois.

6. Recent Tendencies in Land Tenure and Their Significance.

Paper, Geo. Werwein, University of Wisconsin.

Discussion, C. L. Stewart, Office Farm Management and Farm Economics.

7. Replanning the Farm Layout.

Paper, W. I. Myers, Cornell University.

Discussion, R. F. Taber, Ohio State University. 